\title{
Synthesis, Characterization and in vitro, in vivo and in silico Anti-Inflammatory Studies of the Novel Hybrid Based on Ibuprofen and 3-Hydroxy-Copalic Acid Isolated from Copaiba Oil (Copaifera multijuga)
}

\author{
Fábio C. de Souza, ${ }^{a}$ Larissa F. Brito, ${ }^{b}$ Marcos T. Silva,${ }^{c}$ Michelle A. Sugimoto, ${ }^{b}$ Ana Cristina S. Pinto, ${ }^{d}$ \\ Patrícia D. O. de Almeida, ${ }^{a}$ Rodrigo O. S. Souza, ${ }^{a}$ Renyer A. Costa ${ }^{c}$ Fernanda Guilhon-Simplicio, ${ }^{\oplus a}$ \\ Almir G. Wanderley, ${ }^{e}$ Kelson M. T. de Oliveira, ${ }^{c}$ Lirlândia P. Sousa, ${ }^{b}$ Valdir F. da Veiga-Junior ${ }^{\circledR} *, c_{f} f$ \\ and Emerson S. Lima ${ }^{\circledR a}$ \\ ${ }^{a}$ Faculdade de Ciências Farmacêuticas, Universidade Federal do Amazonas, 69067-005 Manaus-AM, Brazil \\ ${ }^{b}$ Faculdade de Farmácia, Universidade Federal de Minas Gerais, 31270-901 Belo Horizonte-MG, Brazil \\ 'Departamento de Química, Universidade Federal do Amazonas, 69067-005 Manaus-AM, Brazil \\ 'Instituto Nacional de Pesquisas da Amazônia, 69067-375 Manaus-AM, Brazil \\ ${ }^{e}$ Departamento de Fisiologia e Farmacologia, Universidade Federal de Pernambuco, \\ 50670-420 Recife-PE, Brazil
}

Instituto Militar de Engenharia, 22290-270 Rio de Janeiro-RJ, Brazil

\begin{abstract}
A novel anti-inflammatory hybrid 3-ibuprofenyl-copalic acid (3-IbuCA) was synthesized from 3-hydroxy-copalic acid isolated from Amazonian copaiba oil (Copaifera multijuga Hayne), and the anti-inflammatory ibuprofen. After full characterization, several assays to verify its anti-inflammatory effects were performed in vitro, in vivo and in silico (molecular docking). Induced fit docking was performed to observe the interactions with the enzymes cyclooxygenase-1 (COX-1) and cyclooxygenase-2 (COX-2). In vitro tests of cytotoxicity and tumor necrosis factor (TNF)- $\alpha$ inhibition, and in vivo tests of pleurisy, protein expression and gastrocytotoxicity were performed. Molecular docking studies with COX-1 and 2 showed binding free energies $(\Delta \mathrm{G})$ of -2.2 and $-7.8 \mathrm{kcal} \mathrm{mol}^{-1}$, respectively, while for mofezolac and indomethacin, the binding free energies $\Delta \mathrm{G}$ presented values of -8.5 and $-10.1 \mathrm{kcal} \mathrm{mol}^{-1}$, which makes 3-IbuCA selective for COX-2 inhibition. This hybrid showed no toxicity against human macrophage at concentrations up to $2 \mu \mathrm{M}$, and inhibited TNF- $\alpha$ production in lipopolysaccharide (LPS)-stimulated macrophages. In the pleurisy assays, 3-IbuCA reduced the total leukocytes and mononuclear cells, which was followed by reduction of $\mathrm{p}-\mathrm{IKB} \alpha$ (phosphorylated nuclear factor of kappa light polypeptide gene enhancer in B-cells inhibitor, alpha) protein expression. Compared with ibuprofen alone, the hybrid caused less gastric damage. Thus, the docking, together with in vitro and in vivo studies suggest that this novel hybrid has potential as a new anti-inflammatory agent.
\end{abstract}

Keywords: 3-hydroxy-copalic acid, ibuprofen, Amazonia, copaiba, anti-inflammatory action

\section{Introduction}

Copaiba oil is an oilresin exuded from the trunk of trees of the Copaifera genus (Fabaceae), which is widely distributed throughout the Amazon region, as well as in Central and Eastern regions of Brazil. Copaiba oil is commonly used in folk medicine to treat numerous diseases, such as ulcers, wounds, syphilis, bronchitis, and

*e-mail: valdir.veiga@gmail.com inflammation. ${ }^{1}$ Its chemical composition has significant amounts of terpenoids, particularly sesquiterpene hydrocarbons, such as caryophyllene and humulene, and diterpenic acids from clerodane, kaurane and labdane skeletons, with the latter being the most abundant, as well as copalic acid (a copaiba oil biomarker) and its derivatives: 3-acetoxy-copalic acid and 3-hydroxy-copalic acid (3-HCA). ${ }^{1,2}$ Anti-inflammatory, antileishmanial and antitumor properties have been ascribed to several copaiba oils, their fractions and isolated compounds, sometimes 
showing strong synergistic effects. ${ }^{3}$ Copaifera multijuga Hayne is a copaiba oil producing species commonly found in Central and Western Amazonia, ${ }^{4}$ as a well-studied oil, ${ }^{5}$ its diterpenes have been isolated and their biological activities have been assessed, such as the antigenotoxicity of copalic acid and the antileishmanial effect of its 3-hydroxy derivative (3-HCA). ${ }^{6}$

Ibuprofen is a 2-methyl-propyl-phenyl propionic acid and was the first member of propionic acid derivatives to be introduced in 1969 as a better alternative to acetyl salicylic acid. However, gastric discomfort, nausea, and vomiting still persist as side effects of ibuprofen, although to a lesser degree than acetyl salicylic acid. Ibuprofen is the most commonly prescribed and used non-steroidal antiinflammatory drug (NSAID) with non-selective inhibition of cyclooxygenase-1 (COX-1) and cyclooxygenase-2 $(\mathrm{COX}-2){ }^{7}$ Although ibuprofen is less potent than some other NSAIDs, it still has important anti-inflammatory, analgesic and antipyretic effects, due to its inhibitory action of cyclooxygenases with consequent reduction of prostaglandins. $^{\text {? }}$

Structural modifications of diterpenic acids with recognized anti-inflammatory effects, such as kaurenoic and copalic acids and their derivatives, have recently been produced with the purpose of potentiating the anti-inflammatory activity and reducing the side effects. Such modifications can enable new molecules to be lead compounds at the future pharmaceutical market adding value to public health. Reactions of esterification and acylation insert functional clusters that decrease the polarity of the molecules facilitating their permeability in cell membranes. For this reason, esterification is considered an excellent method for developing drugs with improved biological activity. ${ }^{8}$

In modern drug research and development, protein binders play an important role in predicting the orientation of the linker to a receptor or enzyme using electrostatic interactions to quantify it, including Van der Waals interactions. The sum of all these interactions are approximated by a fitting score, which represents the bonding potential. In simpler rigid body systems, the ligand is screened in a six-dimensional rotational or translational space to fit the binding site, which may serve as the primary compound for choosing the best molecular structure of the drugs under study. However, docking studies are indispensable in drug development, since docking procedures are improved by several groups, allowing the flexibility of the receptor and the ligand. In the case of nonselective COX-2 inhibitors, such as ibuprofen, it is of the utmost importance to clarify the affinity relationships of COXs after chemical modifications by synthetic processes. ${ }^{9}$
In this sense, taking advantage of the biological activities of substances in copaiba oil such as 3-HCA, and the properties of ibuprofen, we propose the synthesis of a new substance, the hybrid 3-ibuprofenyl-copalic acid (3-IbuCA) as a potential new anti-inflammatory agent.

\section{Experimental}

\section{Computational evaluation}

Molecular docking calculations were performed on AutoDock-Vina, ${ }^{10}$ which uses a scoring function consisted in a number of sequential steps that involves a random perturbation of the conformation followed by a local optimization using the Broyden-Fletcher-Goldfarb-Shanno algorithm, being useful to predict the non-covalent binding of macromolecules or, more frequently, of a macromolecule (receptor) and a small molecule (ligand) efficiently. ${ }^{10} \mathrm{X}$-ray crystal structures of COX-1 and COX-2 (cyclooxygenase-1 and cyclooxygenase-2, target enzymes for 3-IbuCA) were obtained from the Protein Data Bank web site ${ }^{11}$ with ID 5WBE and 4COX, respectively. The ligands (mofezolac and indomethacin) and water molecules were removed, Gasteiger charges were assigned and the macromolecule was saved in PDBQT file format using Auto docking Vina Tools (ADVT). A grid box size of $18 \times 16 \times 16 \AA$ centered at 36.220 ( $x$-axis), 163.736 (y-axis) and 27.489 (z-axis) was implemented at the active site of COX-1, while for COX-2 the dimensions of $20 \times 20 \times 20 \AA$ centered at 24.150 ( $x$-axis), 22.800 ( $y$-axis) and 12.900 (z-axis) were considered for the grid box at the active site. The validation of the accuracy of docking protocol was made by removing the co-crystallized inhibitors (mofezolac and indomethacin) and then docking it at the same site. The superimposition of the structures showed root mean square deviation (RMSD) 0.533 (COX-1) and RMSD 0.963 (COX-2). RMSD values up to $2 \AA$ are considered reliable for a docking protocol. ${ }^{12}$ All the structures used in the docking calculations were modeled in the Gaussian 09 program $^{13}$ and optimized at the density functional theory (DFT) level using B3LYP (Becke, 3-parameter, Lee-Yang-Parr) exchange-correlation functional with 6-31G(d) basis set.

Nuclear magnetic resonance (NMR) experiments were performed in a Bruker Ascend ${ }^{\mathrm{TM}} 11.75$ Tesla. ${ }^{1} \mathrm{H}$ and ${ }^{13} \mathrm{C}$ NMR shifts $(\delta)$ were reported in parts per million (ppm) with respect to dichloromethane. Coupling constants $(J)$ were reported in hertz $(\mathrm{Hz})$. Signal multiplicity was assigned as singlet (s), doublet (d), doublet of doublets (dd) and multiplet (m). Mass spectrometry (MS) experiments were performed by direct infusion of samples in high purity methanol on a LCQ Fleet (Thermo Scientific). 
$\mathrm{ACD} /$ ChemSketch freeware ${ }^{14}$ was used to draw the molecules. Melting points were determined on the PFM II apparatus (Tecnopon).

Isolation of 3-hydroxy-copalic acid (3-HCA)

3-Hydroxy copalic acid (3-HCA) was obtained from a Copaifera multijuga Hayne copaiba oil that was previously collected, ${ }^{5}$ and stored under refrigeration. Separation of 3-HCA and other diterpenic carboxylic acids present in copaiba oil was performed using $\mathrm{SiO}_{2}-\mathrm{KOH}$ column chromatography, as described to copaiba oils previously. ${ }^{15}$ Separation of 3-HCA from the mixture of Copaifera multijuga acids (copalic, 3-acetoxy-copalic, agathic and pinifolic) was performed by sequential open column chromatography procedures using hexane and ethyl acetate in silica gel and recrystallization.

\section{Synthesis of 3-IbuCA}

The reaction was performed as follows: 3-hydroxycopalic acid $(32.0 \mathrm{mg}, 0.100 \mathrm{mmol})$ was mixed with $N, N^{\prime}$-dicyclohexylcarbodiimide (DCC, $40.8 \mathrm{mg}$, 0.1977 mmol, Sigma-Aldrich, São Paulo, Brazil), 4-(dimethylamine)-pyridine (DMAP, Sigma-Aldrich, São Paulo, Brazil) spatula tip and ibuprofen $(26.4 \mathrm{mg}$, 0.1279 mmol, Sigma-Aldrich, São Paulo, Brazil) in dry dichloromethane (DCM, $5 \mathrm{~mL}$, Anidrol, São Paulo, Brazil) under stirring for $2 \mathrm{~h}$. After this time the reaction was terminated by addition of distilled water $(10 \mathrm{~mL})$. The solution was extracted with DCM $(2 \times 5 \mathrm{~mL})$ and the organic phase was dried with anhydrous $\mathrm{Na}_{2} \mathrm{SO}_{4}$. The solution was filtered and evaporated. The residue was recrystallized from EtOAc and separated from the insoluble solid. The EtOAc phase was purified by preparative thin layer chromatography (PTLC) on hex:DCM:EtOAc (7:1:2), yielding white solid (30.0 mg, yield 94\%). Solid amorphous white, yield 94\%, mp 141-143 ${ }^{\circ} \mathrm{C}$; ${ }^{1} \mathrm{H}$ NMR (500 MHz, $\left.\mathrm{CDCl}_{3}\right) \delta 7.22(\mathrm{~d}, 2 \mathrm{H}, J 3.0 \mathrm{~Hz}, \mathrm{CH}), 7.10(\mathrm{~d}, 2 \mathrm{H}, J 3.0 \mathrm{~Hz}$, $\mathrm{CH}), 5.69(\mathrm{~s}, 1 \mathrm{H},=\mathrm{CH}), 4.88\left(\mathrm{~s}, 1 \mathrm{H}, \mathrm{CH}_{2},=\mathrm{CH}_{2}\right), 4.47(\mathrm{dd}$, $\left.1 \mathrm{H}, J 9.0,3.0 \mathrm{~Hz},=\mathrm{CH}_{2}\right), 3.69(\mathrm{~m}, 1 \mathrm{H}, \mathrm{CH}), 3.50(\mathrm{~m}, 1 \mathrm{H}$, $\mathrm{CH}), 2.46\left(\mathrm{~d}, 2 \mathrm{H}, \mathrm{J} 3.0 \mathrm{~Hz}, \mathrm{CH}_{2}\right), 2.41\left(\mathrm{~m}, 1 \mathrm{H}, \mathrm{CH}_{2}\right), 2.33$ $\left(\mathrm{m}, 2 \mathrm{H}, \mathrm{CH}_{2}\right), 2.18\left(\mathrm{~s}, 3 \mathrm{H}, \mathrm{CH}_{3}\right), 1.85(\mathrm{~m}, 1 \mathrm{H}, \mathrm{CH}), 1.54(\mathrm{~m}$, $\left.2 \mathrm{H}, \mathrm{CH}_{2}\right), 1.51$ (s, $\left.2 \mathrm{H}, \mathrm{CH}_{2}\right), 1.51$ (d, $3 \mathrm{H}, J 3.0 \mathrm{~Hz}, \mathrm{CH}_{3}$ ), $1.40\left(\mathrm{~m}, 1 \mathrm{H}, \mathrm{CH}_{2}\right), 1.28\left(\mathrm{~s}, 1 \mathrm{H}, \mathrm{CH}_{2}\right), 1.13\left(\mathrm{~m}, 1 \mathrm{H}, \mathrm{CH}_{2}\right)$, $1.11(\mathrm{~m}, 1 \mathrm{H}, \mathrm{CH}), 1.02$ (s, 3H, $\left.\mathrm{CH}_{3}\right), 0.90\left(\mathrm{~s}, 3 \mathrm{H}, \mathrm{CH}_{3}\right)$, 0.88 (s, 3H, $\left.\mathrm{CH}_{3}\right), 0.80$ (s, 3H, $\left.\mathrm{CH}_{3}\right), 0.72(\mathrm{~m}, 1 \mathrm{H}, \mathrm{CH})$, $0.71\left(\mathrm{~s}, 3 \mathrm{H}, \mathrm{CH}_{3}\right) ;{ }^{13} \mathrm{C} \mathrm{NMR}\left(125 \mathrm{MHz}, \mathrm{CDCl}_{3}\right) \delta 174.4$, $170.8,154.1,140.5,138.2,129.7,129.2,127.6,127.3$, 115.0, 107.1, 80.7, 56.1, 54.6, 45.6, 45.0, 39.9, 39.2, 39.1, $38.2,37.9,30.2,27.8,26.4,25.3,23.6,22.4,22.3,21.0$,
19.4, 18.4, 14.2; MS (ion trap MS (ITMS)) $\mathrm{m} / z$, calcd. for $\mathrm{C}_{33} \mathrm{H}_{48} \mathrm{O}_{4}[\mathrm{M}]^{+}:$508.7313, found: $507.52[\mathrm{M}-\mathrm{H}]^{+}$.

\section{Pharmacological evaluation}

\section{Cell culture and anti-inflammatory assays}

To evaluate the cell viability of treated human macrophages, THP1 (tryptophan hydroxylase 1) monocytes were seeded (50,000 cells per well) in 96-well cell culture plates (BD Biosciences), differentiated into macrophages using $20 \mathrm{ng} \mathrm{mL}^{-1}$ phorbol myristate acetate (PMA, SigmaAldrich, St. Louis, MO, USA) and serum deprived with $0.5 \%$ fetal bovine serum (FBS) for $16 \mathrm{~h}$. Subsequently, cells were treated with or without substances at different concentrations $(2,10$ and $20 \mu \mathrm{M})$ for $2 \mathrm{~h}$, and thereafter with lipopolysaccharide (LPS) (100 $\left.\mathrm{ng} \mathrm{mL}^{-1}\right)$ for an additional $4 \mathrm{~h}$. LPS was added to the wells without removing the supernatant, which means that drugs were present for the entire time of stimulation with LPS. Human monocytic cells from the THP1 strain $\left(\right.$TIB$^{202}{ }^{\circledR}$, American Type Culture Collection $^{\circledast}$, USA) were cultured in Roswell Park Memorial Institute (RPMI) 1640 medium (Cultilab, Diadema, Brazil) supplemented with 10\% FBS (Cultilab, Diadema, Brazil) and maintained at $37{ }^{\circ} \mathrm{C}$ and $5 \% \mathrm{CO}_{2}$. For the assay, $10^{6}$ cells well $^{-1}$ were plated in 24-well culture plates (TPP, Zurich, Switzerland) in $0.5 \mathrm{~mL}$ of the abovementioned supplemented medium. PMA was added to the cell suspension giving a concentration of $2-20 \mathrm{ng} \mathrm{mL}^{-1}$ to differentiate monocytes into macrophages. After $24 \mathrm{~h}$, the monolayers were washed and pre-treated for $2 \mathrm{~h}$ with or without the bioactives previously dissolved in dimethyl sulfoxide (DMSO) and diluted in RPMI 1640 medium at a concentration of $20 \mu \mathrm{g} \mathrm{mL}^{-1}\left(500 \mu \mathrm{L}\right.$ well $\left.{ }^{-1}\right)$. Next, the macrophages were stimulated for $4 \mathrm{~h}$ with LPS (extracted from Escherichia coli serotype O:111:B4) solubilized in RPMI 1640 medium at the final concentration of $100 \mathrm{ng} \mathrm{mL}^{-1}$. Dexamethasone at $20 \mu \mathrm{g} \mathrm{mL}^{-1}$ was used as a positive anti-inflammatory control. The concentration of DMSO in the culture media did not exceed $2 \% \mathrm{v} / \mathrm{v}$. Cells incubated in the absence of LPS were used as negative control. ${ }^{16}$

Quantification of tumor necrosis factor- $\alpha$ (TNF- $\alpha$ ) in cell supernatants

The potential anti-inflammatory activity was evaluated by measuring the cytokine tumor necrosis factor- $\alpha$ (TNF- $\alpha$ ) produced by LPS-stimulated THP1 macrophages, as previously described. ${ }^{16}$ For this, the supernatant was collected, and TNF- $\alpha$ was measured using the cytokinespecific sandwich quantitative enzyme-linked immunesorbent assay (ELISA) according to the manufacturer's 
instructions (TNF- $\alpha$ duo set Elisa kits, R\&D Systems, Minneapolis, USA).

\section{Viability of THP1 cells after treatment with bioactives}

Colorimetric assay of 3-(4,5-dimethylthiazol-2yl)2,5-diphenyl tetrazolium bromide (MTT) was used to evaluate the viability of pretreated THP1 cells with different concentrations of bioactives, followed by activation with LPS. ${ }^{17}$ To this end, THP1 cells were suspended at $2 \times 10^{6}$ cells $\mathrm{mL}^{-1}$ in RPMI medium enriched with $10 \%$ FBS. To induce differentiation, PMA was added to the final $20 \mathrm{ng} \mathrm{mL} \mathrm{mL}^{-1}$ cell suspension. The cells were then transferred to 96-well culture plates and incubated under culture conditions. A total of $10^{6}$ cells were added to each well for a final volume of $100 \mu \mathrm{L}$ per well. In order to eliminate the cells in suspension and debonding the adhered cells, after $24 \mathrm{~h}$ of incubation the supernatant from each well was replaced with RPMI 1640 medium (Cultilab, Diadema, Brazil) enriched with 1\% FBS. The cells were then treated with bioactives dissolved in RPMI 1640 medium at concentrations of 2, 10 and $20 \mu \mathrm{M}$. As control, cells incubated with RPMI medium containing $2 \%$ DMSO, condition representing the maximum amount of DMSO present in the bioactive solutions were used. After $2 \mathrm{~h}$ of incubation under culture conditions, the cells were activated with LPS at the final concentration of $100 \mathrm{ng} \mathrm{mL}^{-1}$. To assess cell viability, the well supernatant was discarded and replaced with $100 \mu \mathrm{L}$ of MTT dissolved in RPMI at the concentration $400 \mu \mathrm{g} \mathrm{mL} L^{-1}$. The plates were then incubated for $2 \mathrm{~h}$ under culture conditions for MTT metabolism. After the incubation time, $100 \mu \mathrm{L}$ of DMSO:isopropanol (1:1) was added to each well and the plate was shaken for $15 \mathrm{~min}$ to dissolve the formazan crystals. The optical density of the wells was read at $570 \mathrm{~nm}$ in spectrophotometer (Spectramax ${ }^{\circledR}$ ).

\section{Animals}

Male BALB/c mice, aged 8-10 weeks, were used. Throughout the experimental period, the animals were housed in appropriate collective cages with adequate ventilation and in 12-h light/dark cycles and an average temperature of $22{ }^{\circ} \mathrm{C}$. The experiment was approved by protocol 83/2015 on the project entitled "Screening of inhibition of TNF- $\alpha$ and acute anti-inflammatory activity of Brazilian plants", with Flávio Amaral as the person responsible, which is in accordance with the ethical principles of animal experimentation adopted by the ethics committee on the use of animals (CEUA, UFMG), and was approved at the meeting of $05 / 26 / 2015$ with validity until 05/26/2020.

\section{Murine model of pleurisy/pleurisy induced by LPS}

Mice (4 animals in the phosphate buffered saline (PBS) group and 5 animals in the other groups) were challenged with LPS (E. coli/O:111:B4) (250 ng well-1) or saline $(0.9 \% \mathrm{NaCl})$. Some group of mice were pre-treated with IBUP, 3-HCA and 3-IbuCA with $100 \mathrm{mg} \mathrm{kg}^{-1}$ for $1 \mathrm{~h}$ before LPS injection. Subsequently, the cells were recovered from the pleural cavity, washed twice with $1 \mathrm{~mL}$ PBS containing $1 \mathrm{mM}$ ethylenediamine tetraacetic acid (EDTA). The choice of LPS dose was previously determined in our laboratory. ${ }^{18}$

\section{Total and differential cell count}

Cells from the pleural cavity were centrifuged at $1200 \mathrm{rpm}$ for $5 \mathrm{~min}$ at $4{ }^{\circ} \mathrm{C}\left(\right.$ ThermoScientific $\left.^{\circledR}\right)$ and the cell pellet was resuspended in $200 \mu \mathrm{L}$ of $3 \%(\mathrm{~m} / \mathrm{v})$ bovine serum albumin (BSA) diluted in $1 \times$ PBS. An aliquot of the cells was diluted 10-fold in the red cell lysing solution (Turk solution imbralab, Ribeirão Preto, Brazil) and, using a Neubauer's chamber, the total cell count was performed. From this count, the cells were cyto-centrifuged at $450 \mathrm{rpm}$ for 5 min using Cytospin (Shandon III) slides with the cells resuspended in $100 \mu \mathrm{L}$ of BSA. ${ }^{19}$

\section{Western blotting}

Inflammatory cells harvested from the pleural cavity were washed with PBS, and whole cell extracts were prepared as described by Sousa et al..$^{18,19}$ Protein amounts were quantified with a Bradford assay reagent from Bio-Rad (Hercules, CA, USA). Extracts ( $40 \mu \mathrm{g}$ ) were separated by electrophoresis on a denaturing $10-15 \%$ polyacrylamidesodium dodecyl sulfate (SDS) gel and electrotransferred to nitrocellulose membranes. Membranes were blocked overnight at $4{ }^{\circ} \mathrm{C}$ with PBS containing $5 \%(\mathrm{~m} / \mathrm{v})$ nonfat dry milk and $0.1 \%$ Tween-20, washed three times with PBS containing $0.1 \%$ Tween-20, and then incubated with specific primary antibodies (anti-anti-phospho-IKB-alpha) using a dilution of 1:1000 in PBS containing $5 \%(\mathrm{~m} / \mathrm{v})$ BSA and $0.1 \%$ Tween-20. After washing, membranes were incubated with appropriate horseradish peroxidase (HRP)-conjugated secondary antibody (1:3000). For normalization of the bands, the same membranes were incubated for $2 \mathrm{~h}$ at r.t. with anti-actin antibody using a dilution of 1:1000 in PBS containing 5\% (m/v) BSA and $0.1 \%$ Tween-20. Immunoreactive bands were visualized by using an enhanced chemiluminescence (ECL) detection system, as described by the manufacturer (GE Healthcare, Piscataway, NJ, USA). The values of phosphorylated levels of $\mathrm{p}-\mathrm{IKB} \alpha$ (phosphorylated nuclear factor of kappa light 
polypeptide gene enhancer in B-cells inhibitor, alpha) were quantified by using a densitometric analysis software (ImageJ). ${ }^{20}$ Changes in protein levels were estimated, and the results were expressed in arbitrary units (AU) normalized to the values of $\beta$-actin in the same sample.

\section{Gastrocytotoxicity assay}

For the evaluation of gastric ulcer induced by absolute ethanol, the methodology was used as described with modifications. ${ }^{21}$ After $18 \mathrm{~h}$, the mice $(\mathrm{n}=6$ per group) were pre-treated orally with ibuprofen (300 $\left.\mathrm{mg} \mathrm{kg}^{-1}\right)$, 3-IbuCA $\left(300 \mathrm{mg} \mathrm{kg}^{-1}\right)$ and the negative control $(0.9 \% \mathrm{NaCl})$. After $1 \mathrm{~h}$ of administration, the mice were euthanized in a $\mathrm{CO}_{2}$ chamber. The stomachs were removed and opened by the great curvature. Then, they were photographed, and the lesions were counted through computerized planimetry using the Image J program. ${ }^{20}$ The results were expressed as total area of ulcerative lesion (ALU, in $\mathrm{mm}^{2}$ ).

\section{Statistical analyses}

Results are presented as mean \pm standard error of the mean (SEM). Data were analyzed by one-way analyses of variance (ANOVA), and differences between groups were assessed using the Students-Newmann-Keuls post hoc test unless otherwise indicated. A $p$-value $<0.05$ was considered significant. Calculations were performed using the Prism 5.0 software program for Windows. ${ }^{22}$

\section{Results and Discussion}

\section{Chemistry}

The diterpene 3-hydroxy-copalic acid (3-HCA) was obtained from the acid fraction of copaiba oil together with several other labdane diterpenes. After normal phase open column chromatography of the copaiba acids, a fraction with well-formed crystals was observed between the oily fractions and 3-HCA was recrystallized in high purity. The target compound was synthesized according to Figure 1. Only a single product resulting from the reaction of 3-hydroxy-copalic acid and ibuprofen was obtained. Ibuprofen is a widely used nonsteroidal anti-inflammatory drug. It has excellent stereoselectivity under moderate reaction conditions. Through the knowledge of the potential anti-inflammatory effect of diterpene acids of copaiba oil, 3-HCA was esterified with ibuprofen in order to verify whether anti-inflammatory activity was better than the natural product. The difference of $\mathrm{p} K_{\mathrm{a}}$ between the molecules favors esterification in the carboxylic

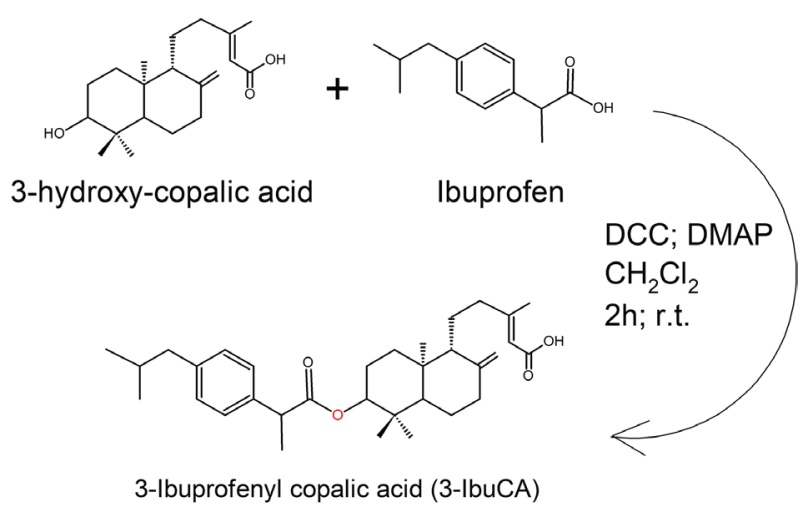

Figure 1. Scheme of synthesis of 3-ibuprofenyl copalic acid (3-IbuCA). Reaction conditions: (a) ibuprofen, $N, N^{\prime}$-dicyclohexylcarbodiimide (DCC), 4-(dimethylamino)-pyridine (DMAP), dichloromethane, room temperature ( $94 \%$ yield).

group of ibuprofen with the hydroxyl of 3-hydroxycopalic acid. Expected mass spectrum and NMR of the substance was obtained and the molecular structure was subsequently identified from specific signals obtained in the literature. ${ }^{21}$

\section{Molecular docking study}

Free energy of binding $(\Delta \mathrm{G})$ analysis demonstrated that 3-IbuCA docked with COX-1 and COX-2 with $\Delta \mathrm{G}$ values of -2.2 and $-7.8 \mathrm{kcal} \mathrm{mol}^{-1}$, respectively, while the inhibitors docked with $\Delta \mathrm{G}$ values of -8.5 and $-10.1 \mathrm{kcal} \mathrm{mol}^{-1}$, respectively. Despite the higher $\Delta \mathrm{G}$ values, binding modes analysis demonstrated that the best modes of 3-IbuCA structure docked at the COX-1 and COX-2 active sites similar to the inhibitors, by alkylalkyl, alkyl-pi interactions and hydrogen bonds with some correlated amino acids to those of the inhibitors (Figures 2, 3 and 4). 3-IbuCA binds at the COX-1 active site by noncovalent interactions with Val 119, Leu 531, Val 116, Ala 527, Ile 523, Tyr 355, Leu 352, Val 349 and His 90 while the inhibitor mofezolac registered weak interactions with Ala 537, Val 349, Leu 351, Ile 523, Leu 352 and Gly 526. Strong intermolecular interactions were also revealed for both ligands, 3-IbuCA showed hydrogen bond interaction between ester group and $\operatorname{Arg} 120$, and pi-cation interaction between the aromatic ring and $\operatorname{Arg} 120$, while mofezolac revealed an ionic interaction between the acid carboxylic and Arg 120. Concerning to COX-2, 3-IbuCA binds at the active site by weak non-covalent interactions with Val 89, Pro 86, Tyr 355, Val 523, Ala 527, Tyr 385, Leu 352, Phe 518, Trp 387, Val 349 and Val 116. Two intermolecular hydrogen bonds were also confirmed between the ester group and Arg 120, and the carboxyl group and Met 522.

These results reveal 3-IbuCA as a better inhibitor of COX-2 than COX-1, which indicates that the interaction with 
(a)

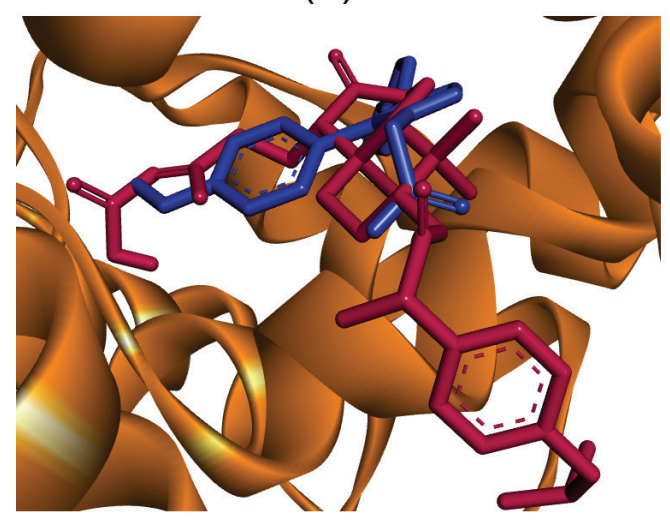

(b)

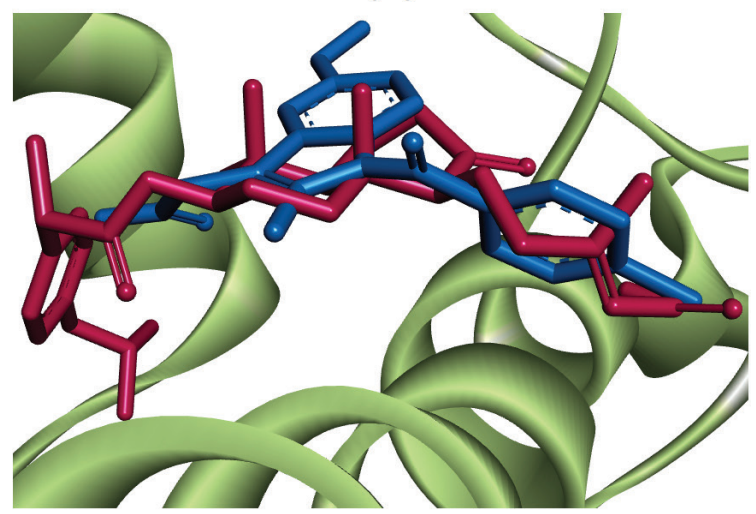

Figure 2. Superimpositions of the docked 3-IbuCA and co-crystallized inhibitors into the COX-1 and COX-2 active sites: (a) comparison of the docked 3-IbuCA (pink) and co-crystallized structure of mofezolac (blue); (b) comparison of the docked 3-IbuCA (pink) and the co-crystallized structure of indomethacin (cyan).

(a)
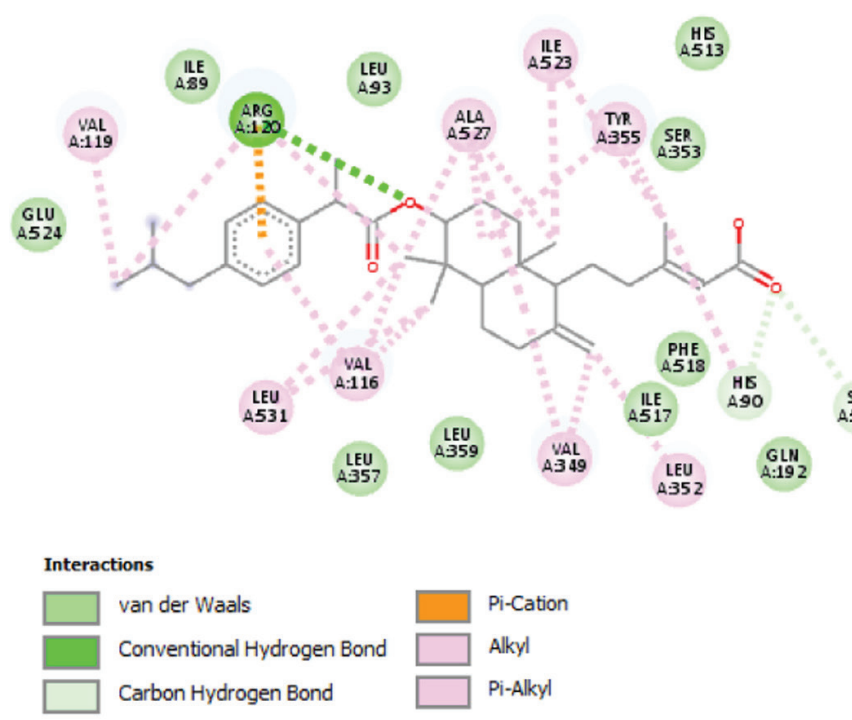

(b)

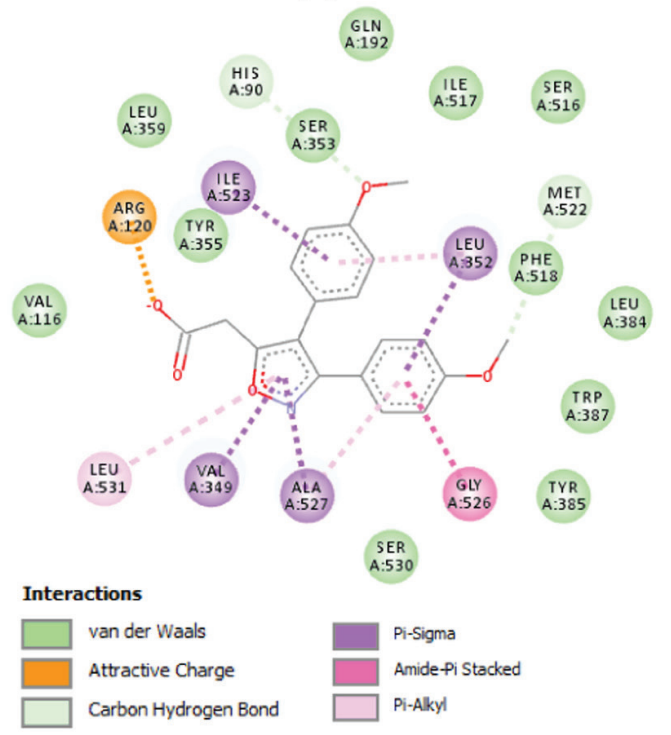

Figure 3. Bind modes of 3-IbuCA (a) and mofezolac (b) into the active site of COX-1.

COX-2 could be the main factor for the anti-inflammatory activity of this molecule. Indomethacin registered in the active site interactions with Leu 531, Ala 527, Val 349, Leu 352, Val 523, Phe 381, Trp 387, Met 522, Leu 384, Tyr 385. Strong attractive hydrogen bond interaction between ether group and Tyr 355, and ionic interaction between the ester group and Arg 120 were registered, indicating that the interaction with these amino acids is essential for a structure to act as a possible inhibitor of this enzyme.

Good anti-inflammatory molecules that promote an effective inhibition of COX-1 have been shown to involve the binding pocket of Arg 120, Tyr 355, Val 116, Val 349, Met 522, Ile 523, Ala 527 and Ser 530 amino acids. ${ }^{23}$ Ibuprofen $\left(\Delta \mathrm{G}=-8.6 \mathrm{kcal} \mathrm{mol}^{-1}\right)$ binds to all these amino acids, featuring three hydrogen bonds at the mouth of COX-1, two with Arg 120 and one with Tyr 355. 3-IbuCA binds to four of these groups, however, only one strong interaction (Arg 120) was observed, which supports that the structural modification promoted in ibuprofen decreases its inhibition against COX-1. For COX-2, 3-IbuCA was shown to be more interactive, in fact, the addition of the 3-hydroxy-copalic-acid inhibited the formation of a second hydrogen bond with Tyr 355 in COX-1, which is seen to be the factor of the lowest $\Delta \mathrm{G}$ value for ibuprofen registered in docking calculations. Comparing the 3-IbuCA and indomethacin binding pockets, the studied structure does not interact just with Gly 526 and Ile 523, the interactions involved in 3-IbuCA docked to COX-2 are very similar to those of indomethacin. 
(a)

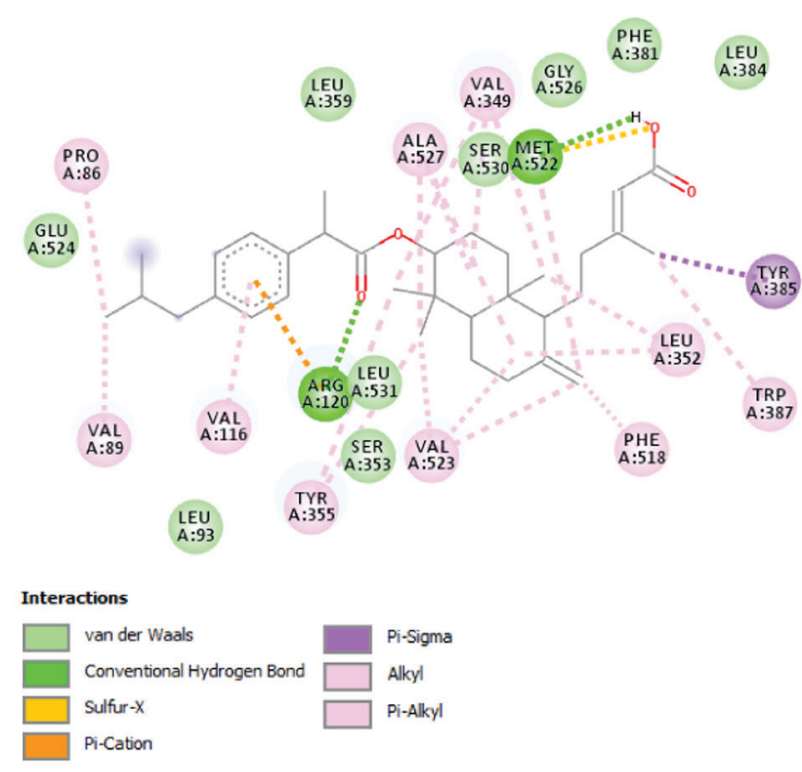

(b)

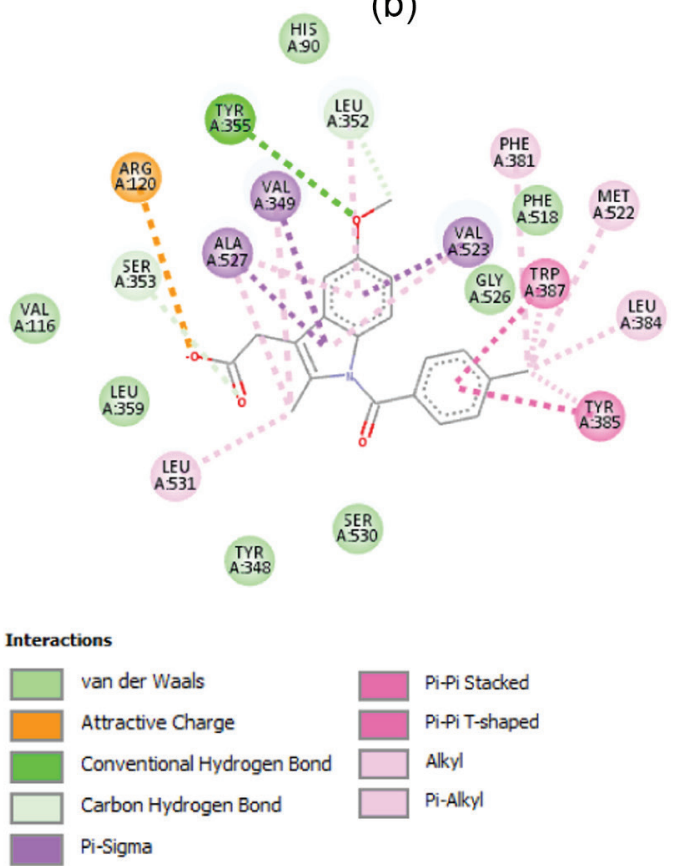

Figure 4. Bind modes of 3-IbuCA (a) and indomethacin (b) into the active site of COX-2.

\section{Pharmacology}

Viability assay

The cytotoxicity of ibuprofen (Figure 5), 3-HCA and 3-IbuCA, was evaluated in THP1 cells with MTT assay. It was observed that none of the compounds reduced cell viability in the lowest concentration tested $(2 \mu \mathrm{M})$. At $10 \mu \mathrm{M}$ only the new derivative 3 -IbuCA causes reduction in cell viability. In the highest dose tested, cell viability

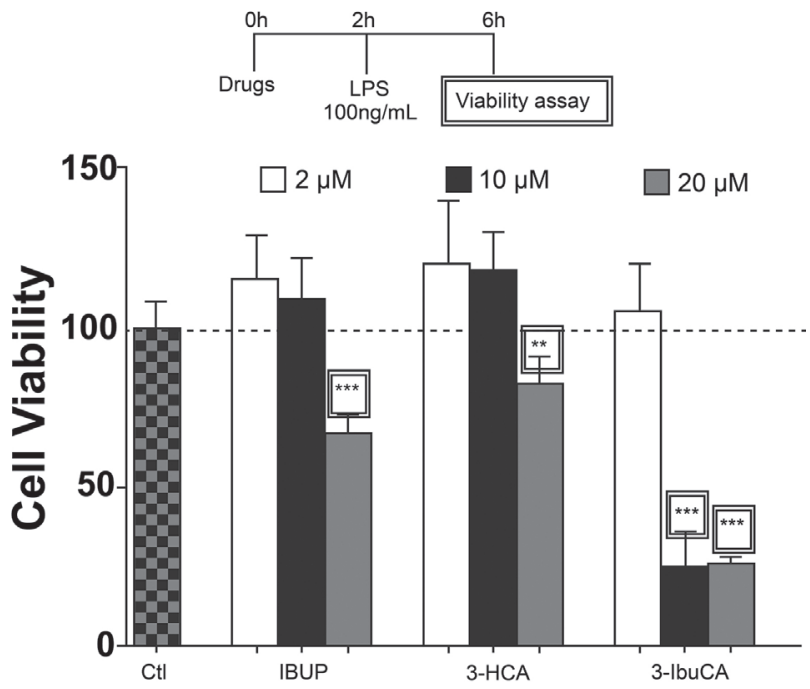

Figure 5. Viability of THP1 (human monocytic cell line) cells pre-treated with IBUP, 3-HCA and 3-IbuCA in different concentrations (2, 10 and $20 \mu \mathrm{M}$ ), followed by LPS stimulation. Data are expressed as the percentage of viable cells in relation to the control (mean \pm SEM). $* * p<0.01$ and $* * * p<0.001$ compared to the control group (ANOVA). was greater than $60 \%$ for both ibuprofen and 3-HCA, but lower than $25 \%$ for 3 -IbuCA. Thus, coupling of ibuprofen to 3-HCA leads to increased cell cytotoxicity at 10 and $20 \mu \mathrm{M}$ compared to ibuprofen and 3-HCA alone. For this reason, the lowest concentration was used in the following assays with human macrophages. Each mechanism has a different time course for injury induction to the toxicity, which is influenced by the high molecular weight of the formed component and the binding position of ibuprofen. ${ }^{24}$

\section{In vitro TNF- $\alpha$ inhibition assay}

LPS-activated THP1 cells treated with 3-IbuCA showed inhibition of TNF- $\alpha$ compared to the control group as shown in Figure 6. This result is corroborated by the previously published in vivo results, ${ }^{25}$ confirming the inhibition on COX-2 by ibuprofen.

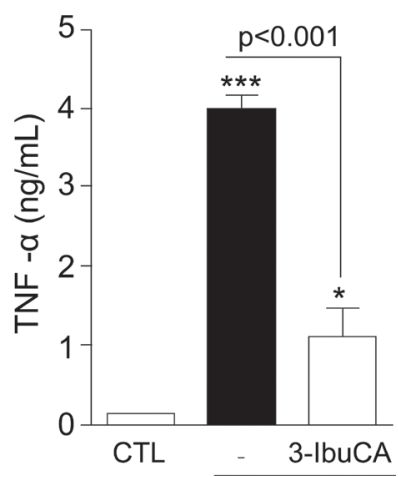

Figure 6. Inhibition of TNF- $\alpha$ in LPS-activated THP1 cells and treated with 3-IbuCA concentration in $2 \mu \mathrm{M}$. 
In vivo model of pleurisy induced by LPS

The anti-inflammatory activity of the semi-synthetic derivative of 3-hydroxy-copalic acid with ibuprofen in an LPS-induced pleurisy model was evaluated (Figure 7). 3-IbuCA caused a significant reduction in the total number of cells and mononuclear cells, which was concluded by an important anti-inflammatory action, being considered the gold-standard model in the evaluation of this biological activity with important prospects for new studies. ${ }^{25,26}$ After treatment with 3-IbuCA, ibuprofen, and 3-HCA protein expression of $\mathrm{p}-\mathrm{IKB} \alpha$ by western blot was performed. The level of $\mathrm{p}-\mathrm{IKB} \alpha$ was reduced after treatment with 3-HCA compared with ibuprofen or 3-IbuCA treatment. The reduction of the protein expression of $\mathrm{p}-\mathrm{IKB} \alpha$ suggests an important reduction of protein translocation to the cell nucleus reducing the inflammatory process. ${ }^{26,27}$

\section{Gastrotoxicity assay}

The 3-IbuCA was further evaluated for potential ulcerogenic effects in terms of ulcer index (Figure 8). The results obtained from the postmortem studies of animals sacrificed at 1, 2 and $4 \mathrm{~h}$ after the action of the substances revealed their safety in relation to the gastric mucosa of $\mathrm{BALB} / \mathrm{c}$ mice compared to ibuprofen.

3-IbuCA presented a satisfactory result regarding gastroprotection since no lesions of the stomach mucosa were observed in BALB/c mice after the standardized periods. This can be due to the modification in the ibuprofen with the suppression of the carboxyl group, responsible for gastrotoxicity. ${ }^{23}$

\section{Conclusions}

The hybrid 3-IbuCA showed anti-inflammatory action against COX-2. Despite the cytotoxicity observed in human macrophages in vitro, 3-IbuCA presented less gastrocytotoxicity than ibuprofen in mice, with less ulcerogenic action observed in the histopathological studies. Mechanistically, 3-IbuCA caused non-selective inhibition of COX-2. In vitro tests demonstrated a significant reduction of TNF- $\alpha$. In vivo, 3-IbuCA presented anti-inflammatory effects in a model of acute inflammation with decreased leukocyte accumulation in the pleural cavity
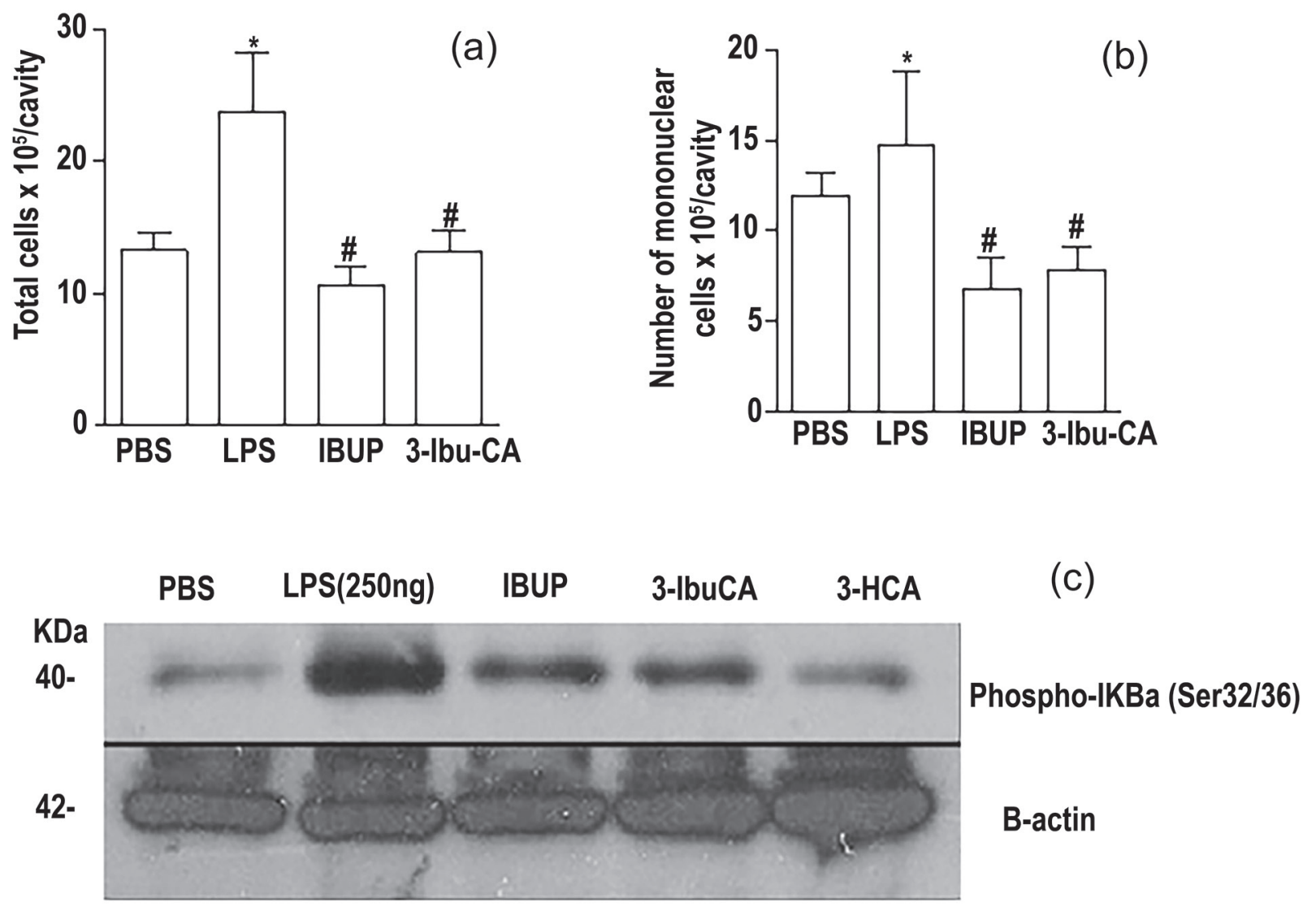

Figure 7. Effect of the 3-IbuCA in pleurisy induced by LPS in reduction of (a) total cells and (b) mononuclear cells; (c) expression key molecule inflammation signaling pathway $(\mathrm{p}-\mathrm{IKB} \alpha)$ in dose-response assay LPS-activated THP-1 cells. For the control, membranes were re-probed with anti- $\beta$-actin. Cell extracts were collected after the in vivo assay and processed for western blot analysis. Blot are representative of two independent experiments using pooled cells from at least four mice. ${ }^{*} p<0.05$ when compared to animals injected with PBS and ${ }^{\sharp} p<0.05$ when compared to animals challenged with LPS. 

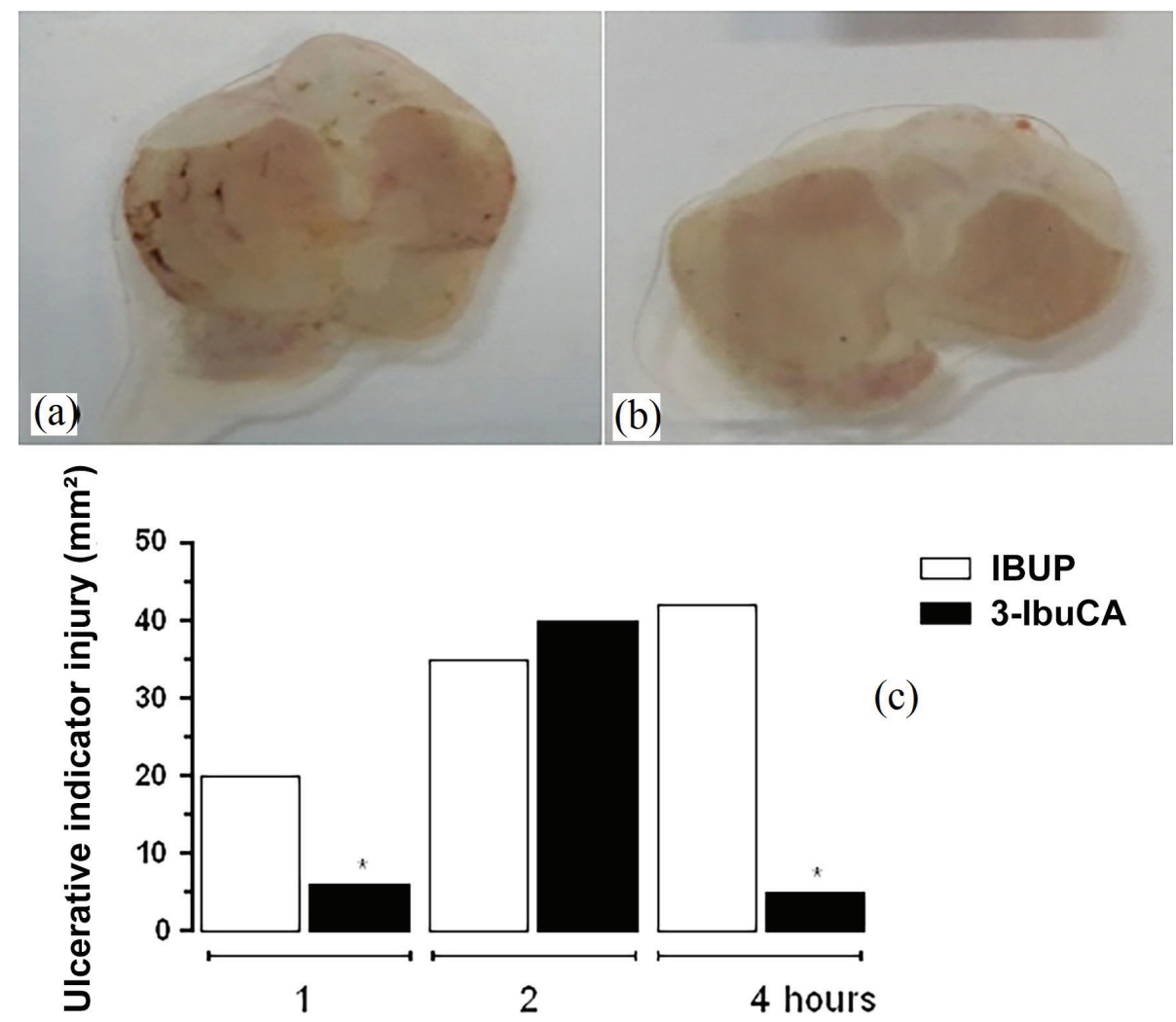

Figure 8. Photomicrographs (10x magnification) of (a) ibuprofen 4 h, (b) 3-IbuCA 4 h treated groups in mice stomach tissues. Macroscopically, no lesions were observed using a computerized system. (c) Effect of the ester derivative 3-IbuCA in comparison with IBUP (ibuprofen) on the gastrocytotoxicity model in BALB/c mice. Three (03) animal groups treated with IBUP (ibuprofen) and three (03) groups treated with 3-IbuCA being sacrificed after 1, 2 and $4 \mathrm{~h}$ for macroscopic analysis. *Measurements of lesions ( $\mathrm{mm}$ ) of 3-IbuCA compared to IBUP at 1 and $4 \mathrm{~h}$ were lower.

in response to LPS. Also, 3-IbuCA caused a significant reduction in $\mathrm{IKB} \alpha$ protein phosphorylation. It is therefore suggested that the semi-synthesized substance (3-IbuCA) is a promising inhibitor of COX-2, and it is necessary to perform new in vivo studies.

\section{Acknowledgments}

The authors thank to financial support from Fundação de Amparo à Pesquisa do Estado do Amazonas (FAPEAM), Conselho Nacional de Desenvolvimento Científico e Tecnológico (CNPq) and Coordenação de Aperfeiçoamento de Pessoal de Nível Superior (CAPES).

\section{References}

1. Arruda, C.; Mejía, J. A. A.; Ribeiro, V. P.; Borges, C. H. G.; Martins, C. H. G.; Veneziani, R. C. S.; Ambrosio, S. R.; Bastos, J. K.; Biomed. Pharmacother. 2019, 109, 1; Veiga Jr., V. F.; Pinto, A. C.; Quim. Nova 2002, 25, 273.

2. Trindade, R.; Silva, J. K.; Setzer, W. N.; Int. J. Mol. Sci. 2018 , 19, 1511; Vargas, F. S.; Almeida, P. D. O.; Aranha, E. S. P.; Boleti, A. P. A.; Newton, P.; Vasconcellos, M. C.; Veiga Jr., V. F.; Lima, E. S.; Molecules 2015, 20, 6194; Leandro, L. M.;
Vargas, F. S.; Barbosa, P. C. S.; Neves, J. K. O.; Silva, J. A.; Veiga Jr., V. F.; Molecules 2012, 17, 3866.

3. Barbosa, A. L. P.; Wenzel-Storjohann, A.; Barbosa, J. D.; Zidorn, C.; Peifer, C.; Tasdemir, D.; Cicek, S. S.; J. Ethnopharmacol. 2019, 233, 94; Izumi, E.; Ueda-Nakamura, T.; Veiga Jr., V. F.; Pinto, A. C.; Nakamura, C. V.; J. Med. Chem. 2012, 55, 2994; Lima, S. R. M.; Christo, H. B.; Veiga-Junior, V. F.; Pinto, A. C.; Fernandes, P. D.; Phytother. Res. 2003, 17, 1048; Veiga-Junior, V. F.; Zunino, L.; Calixto, J. B.; Patitucci, M. L.; Pinto, A. C.; Phytother. Res. 2001, 15, 476.

4. Medeiros, R. S.; Vieira, G.; Almeida, D. R. A.; Fo, M. T.; For. Ecol. Manage. 2018, 414, 85; Martins-da-Silva, R. C. V.; Pereira, J. F.; Lima, H. C.; Rodriguesia 2008, 59, 455.

5. Barbosa, P. C. S.; Wiedemann, L. S. M.; Medeiros, R. S.; Vieira, G.; Sampaio, P. T. B.; Veiga Junior, V. F.; Chem. Biodiversity 2013, 10, 1350; Barbosa, P. C. S.; Medeiros, R. S.; Sampaio, P. T. B.; Vieira, G.; Wiedemann, L. S. M.; Veiga-Junior, V. F.; J. Braz. Chem. Soc. 2012, 23, 1823.

6. Alves, J. M.; Leandro, L. F.; Senedese, J. M.; Castro, P. T.; Pereira, D. E.; Resende, F. A.; Campos, D. L.; Silva, J. J. M.; Varanda, E. A.; Bastos, J. K.; Ambrosio, S. R.; Tavares, D. C.; J. Toxicol. Environ. Health 2018, 81, 116; Santos, A. O.; Izumi, E.; Ueda-Nakamura, T.; Dias Filho, B. P.; Veiga Jr., V. F.; Nakamura, C. V.; Mem. Inst. Oswaldo Cruz 2013, 108, 59. 
7. Ortega-Álvaro, A.; Berrocoso, E.; Rey-Brea, R.; Leza, J. C.; Mico, J. A.; Life Sci. 2012, 90, 13; Bushra, R.; Aslam, N.; Oman Med. J. 2010, 25, 155; Theodoluz, C.; Delporte, C.; ValenzuelaBarra, G.; Silva, X.; Cádiz, S.; Bustamante, F.; Mariano, P.; Schmeda-Hirschmann, G.; Molecules 2015, 20, 11219.

8. Acevedo, C. H.; Scotti, L.; Alves, M. F.; Diniz, M. D. F. M.; Scotti, M. T.; Lett. Org. Chem. 2019, 16, 81; Matos, P. M.; Mahoney, B.; Chan, Y.; Day, D. P.; Cabral, M. M. W.; Martins, C. H. G.; Santos, R. A.; Bastos, J. K.; Page, P. C. B.; Heleno, V. C. G.; Molecules 2015, 20, 18264.

9. Pagala, N. S.; Syed, K.; Tuszynski, J.; Biophys. Rev. 2017, 9 , 91; Shrivastava, S. K.; Srivastava, P.; Bandresh, R.; Tripathi, P. N.; Tripathi, A.; Bioorg. Med. Chem. 2017, 25, 4424.

10. Trott, O.; Olson, A. J.; J. Comput. Chem. 2010, 31, 455.

11. http://www.rcsb.org/pdb/, accessed in October 2019.

12. Costa, R. A.; Junior, E. S. A.; Bezerra, J. A.; Mar, J. M.; Lima, E. S.; Pinheiro, M. L. B.; Mendonça, D. V. C.; Lopes, G. B. P.; Branches, A. D. S.; Oliveira, K. M. T.; J. Chem. 2019, 2019, DOI 10.1155/2019/9627404.

13. Frisch, M. J.; Trucks, G. W.; Schlegel, H. B.; Scuseria, G. E.; Robb, M. A.; Cheeseman, J. R.; Scalmani, G.; Barone, V.; Mennucci, B.; Petersson, G. A.; Nakatsuji, H.; Caricato, M.; Li, X.; Hratchian, H. P.; Izmaylov, A. F.; Bloino, J.; Zheng, G.; Sonnenberg, J. L.; Hada, M.; Ehara, M.; Toyota, K.; Fukuda, R.; Hasegawa, J.; Ishida, M.; Nakajima, T.; Honda, Y.; Kitao, O.; Nakai, H.; Vreven, T.; Montgomery Jr., J. A.; Peralta, J. E.; Ogliaro, F.; Bearpark, M.; Heyd, J. J.; Brothers, E.; Kudin, K. N.; Staroverov, V. N.; Kobayashi, R.; Normand, J.; Raghavachari, K.; Rendell, A.; Burant, J. C.; Iyengar, S. S.; Tomasi, J.; Cossi, M.; Rega, N.; Millam, J. M.; Klene, M.; Knox, J. E.; Cross, J. B.; Bakken, V.; Adamo, C.; Jaramillo, J.; Gomperts, R.; Stratmann, R. E.; Yazyev, O.; Austin, A. J.; Cammi, R.; Pomelli, C.; Ochterski, J. W.; Martin, R. L.; Morokuma, K.; Zakrzewski, V. G.; Voth, G. A.; Salvador, P.; Dannenberg, J. J.; Dapprich, S.; Daniels, A. D.; Farkas, Ö.; Foresman, J. B.; Ortiz, J. V.; Cioslowski, J.; Fox, D. J.; Gaussian 09; Gaussian Inc., Wallingford, CT, 2009.

14. ChemSketch, version 12.0; ACD/Labs, Toronto, Canada, 2012.

15. Barreto-Jr., A. G.; Biscaia-Jr., E. C.; da Veiga-Jr., V. F.; Pinto, A. C.; Carvalhaes, S. F.; Maciel, M. A.; Quim. Nova 2005, 28, 719.
16. Vago, J. P.; Nogueira, C. R.; Tavares, L. P.; Soriani, F. M.; Lopes, F.; Russo, R. C.; Pinho, V.; Teixeira, M. M.; J. Leukocyte Biol. 2012, 92, 249.

17. Mosmann, T.; J. Immunol. Methods 1983, 65, 55.

18. Sousa, L. P.; Carmo, A. F.; Rezende, B. M.; Lopes, F.; Silva, D. M.; Alessandri, A. L.; Bonjardim, C. A.; Rossi, A. G.; Teixeira, M. M.; Pinho, V.; Biochem. Pharmacol. 2009, 78, 396; Sousa, L. P.; Silva, B. M.; Brasil, B. S.; Nogueira, S. V.; Ferreira, P. C.; Kroon, E. G.; Biochem. Biophys. Res. Commun. 2005, 337, 1065.

19. Sousa, L. P.; Lopes, F.; Silva, D. M.; Tavares, L. P.; Vieira, A. T.; Rezende, B. M.; Carmo, A. F.; Russo, R. C.; Garcia, C. C.; Bonjardim, C. A.; Alessandri, A. L.; Rossi, A. G.; Pinho, V.; Teixeira, M. M.; J. Leukocyte Biol. 2010, 87, 5.

20. http://rsbweb.nih.gov/ij/, accessed in 20 October, 2016.

21. Morimoto, Y.; Oshima, S.; Hara, H. S. T.; Jpn. J. Pharmacol. 1991, 57, 495.

22. Prism 5.0; GraphPad Software, San Diego, CA, USA, 2014.

23. Ahmed, M.; Azam, F.; Gbaj, A.; Zetrini, A. E.; Abodlal, A. S.; Rghigh, A.; Elmahdi, E.; Hamza, A.; Salama, M.; Bensaber, S. M.; Curr. Drug Discovery Technol. 2016, 13, 41; Hegazy, G. H.; Ali, H. I.; Bioorg. Med. Chem. 2012, 20, 1259.

24. Cocco, M. T.; Congiu, C.; Onnis, V.; Morelli, M.; Cauli, O.; Eur. J. Med. Chem. 2003, 38, 513; Curci, A.; Denora, N.; Iacobazzi, R. M.; Ditaranto, N.; Hoeschele, J. D.; Margiotta, N.; Natile, G.; Inorg. Chim. Acta 2017, 472, 221; Bignon, E.; Marazzi, M.; Besancenot, V.; Gattuso, H.; Drouot, G.; Morell, C.; Eriksson, L. A.; Grandemange, S.; Dumont, E.; Monari, A.; Sci. Rep. 2017, 7, 8885 .

25. Wisniewski-Rebecca, E. S.; Rocha, B. A.; Wiirzler, L. A. M.; Cuman, R. K. N.; Velazquez-Martinez, C. A.; Bersani-Amado, C. A.; Chem.-Biol. Interact. 2015, 242, 247.

26. Pérez, D. J.; Díaz-Reval, M. I.; Obledo-Benicio, F.; Zakai, U. I.; Gómez-Sandoval, Z.; Razo-Hernández, R. S.; West, R.; Sumaya-Martines, M. T.; Pineda-Urbina, K.; Ramos-Organillo, A.; Eur. J. Pharmacol. 2017, 814, 14.

27. Smith, R. J.; Iden, S. S.; Rohloff, N. A.; Clin. Immunol. Immunopathol. 1983, 26, 24.

Submitted: April 28, 2019

Published online: November 26, 2019 